\title{
THERMAL REGULATION OF GLACIER SURGING
}

\author{
By Garry K. C. Clarke \\ (Department of Geophysics and Astronomy, University of British Columbia, Vancouver, \\ British Columbia V6T i W5, Canada)
}

Abstract. A necessary condition for a glacier to surge by thermal instability is that the glacier be cold with basal ice at or near the melting point. Deep temperature measurements show that two small surge-type glaciers in the Yukon Territory meet this requirement, but shallow measurements in three other surge-type glaciers suggest a temperate regime. If the latter observations are accepted, not all surges are thermally controlled: if a single mechanism accounts for all surges it cannot be thermal instability.

In this paper it is argued that thermal instability remains a viable mechanism for explaining surges of many cold glaciers, and that regardless of the underlying mechanism, thermal processes must at least have a major influence on the surge behavior of cold glaciers.

Two numerical modelling experiments are described. The first involves a one-dimensional model which shows that thermal control can account for the remarkably constant surge cycle found in some glaciers. The second, a two-dimensional model of the time-dependent temperature structure of a surge-type glacier, shows that the relative amounts of temperate and cold basal ice can change considerably as the surge cycle progresses. This variation alone may be sufficient to explain surges, but even if this is not the case, thermal processes must affect the timing of surges in many cold glaciers.

A compelling feature of the thermal instability mechanism is that it offers an explanation of the factors controlling the non-random geographical distribution of surge-type glaciers. For a glacier to have a cold surface and near-temperate bed, the ice thickness, temperature, and geothermal flux must be fortuitously related.

RÉsumÉ. Régulation thermique des crues glaciaires. Une condition nécessaire pour qu'un glacier subisse une crue par instabilité thermique, est que le glacier soit froid avec une glace à la base au point de fusion ou proche de ce point. Des mesures de températures en profondeur montrent que deux petits glaciers "à crues" dans le Territoire du Yukon, remplissent cette condition, mais que des mesures profondes de température en trois autres glaciers de type "à crues" suggèrent un régime tempéré. Si on accepte ces dernières observations, toutes les crues ne sont pas contrôlées par la température; si un mécanisme unique préside à toutes les crues, ce ne peut être l'instabilité thermique.

Dans cet article, on prouve que l'instabilité thermique reste un mécanisme plausible pour expliquer les crues de beaucoup de glaciers froids et que, quelque soit le mécanisme de base, les phénomènes thermiques doivent au moins avoir une influence prédominante sur le comportement en crue des glaciers froids.

On décrit deux expériences de simulation numérique. La première concerne un modèle uni-dimensionel qui montre que le contrôle thermique peut rendre compte du cycle remarquablement constant des crues de quelques glaciers. La seconde, un modèle bi-dimensionel de la relation temps-température dans un glacier "à crues", montre que la proportion relative de glace de fond, froide ou tempérée, peut changer considérablement quand le cycle de la crue progresse. Cette variation seule peut suffire à expliquer les crues, mais, même si ce n'est pas le cas, les phénomènes thermiques doivent régler le calendrier des crues dans beaucoup de glaciers froids.

Une caractéristique nécessaire du mécanisme d'instabilité thermique est qu'il offre une explication des facteurs contrôlant la distribution géographique non aléatoire des glaciers "à crues". Pour un glacier, avoir une surface froide et un lit approximativement tempéré représente la coïncidence fortuite d'une certaine épaisseur, d'une certaine température de la glace et d'un certain flux géothermique.

Zusammenfassung. Thermische Steuerung eines Gletscher-Ausbruchs. Eine notwendige Bedingung für den Ausbruch eines Gletschers infolge thermischer Instabilität besteht darin, dass das Eis am Untergrund des kalten Gletschers sich am oder nahe am Schmelzpunkt befindet. Temperaturmessungen in der Tiefe zeigen, dass zwei kleine, zu Ausbrüchen neigende Gletscher im Yukon Territory diese Bedingung erfüllen, hingegen lassen seichte Messungen in drei anderen Gletschern desselben Typs einen temperierten Aufbau vermuten. Erweisen sich diese Messungen als richtig, so werden nicht alle Ausbrüche thermisch ausgelöst: wenn allen Ausbrüchen nur ein Mechanismus zugrunde liegt, so kann dies nicht thermische Instabilität sein.

Die Arbeit weist nach, dass thermische Instabilität mit vollem Recht als Mechanismus zur Erklärung der Ausbrüche vieler kalter Gletscher angenommen werden kann und dass - unbeschadet des auslösenden Mechanismus - thermische Prozesse zumindest einen erheblichen Einfluss auf das Ausbruchsverhalten kalter Gletscher haben müssen.

Es werden zwei numerische Modellversuche beschrieben. Der erste stützt sich auf ein eindimensionales Modell, aus dem hervorgeht, dass thermische Steuerung für den bemerkenswert gleichmässigen Ausbruchszyklus einiger Gletscher massgeblich sein kann. Der zweite, ein zweidimensionales Modell der zeitabhängigen Temperaturstruktur eines zu Ausbrüchen neigenden Gletschers, zeigt, dass sich das Massenverhältnis zwischen temperiertem und kaltem Eis am Untergrund im Ablauf des Ausbruchzyklus beträchtlich ändern kann. Diese Änderung allein kann zur Erklärung von Ausbrüchen schon genügen, doch auch wenn dies nicht zutrifft, müssen thermische Prozesse den Ablauf der Ausbrüche an vielen kalten Gletschern steuern.

Eine überzeugende Eigenschaft des Mechanismus auf der Basis thermischer Instabilität ist seine Fähigkeit zur Erklärung der Einflussgrössen für die nicht-zufällige geographische Verteilung ausbrechender Gletscher. Dem an einem Gletscher, der eine kalte Oberfäche und einen fast temperierten Untergrund aufweist, müssen Eisdicke, Temperatur und geothermischer Wärmefluss zufällig miteinander verknüpft sein. 


\section{INTRODUCTION}

The hypothesis that glacier surges are caused by changes in the ice temperature near the base of a cold glacier was first advanced by Robin (1955) and has come to be known as the "thermal instability mechanism". * The idea is attractively simple. Glaciers with temperate beds can slide; those with cold beds cannot. If under some circumstances the bed temperature oscillates between the melting point and lower temperatures, sliding is alternately switched on and off. The cycle of advance and quiescence characteristic of surging glaciers might then be explained.

In his original description of this mechanism Robin wrote as follows:

" . . . if the basal ice temperature in such an ice sheet or glacier is raised by some phenomenon - the most likely one being by an increase in ice movement over the bed-the shear stress due to the greater ice thickness formerly accumulated will be in excess of that required to make the ice flow at this higher temperature. As this is an unstable state the flow may continue to increase until the basal temperature reaches melting point, leading finally to a relatively rapid advance of the glacier front. With basal temperatures now at melting point the flow and ice thickness may remain similar to that of a temperate glacier until conduction and the downward 'advection' of cold ice again start to lower the temperature of the ice rock interface with consequent thickening of the glacier. Such a chain of events may well be cyclic with a very long period."

The are two important points to note in this account of the surge mechanism: the glacier bed is brought to the melting point by some form of creep instability whereby deformational heating warms the basal ice to the melting point; secondly it is implied that the surge is stopped by advective cooling of the ice-rock interface.

In a later restatement of the thermal instability hypothesis Robin ( 1969 ) appears to have modified his view slightly:

"At the start of a cycle, ice temperatures are below meliing point at all depths, so that little or no sliding occurs. As the ice increases in thickness, this increases the basal shear stress and the rate of deformation, with a consequent generation of frictional heat in the lowest levels. This warmer basal ice will then deform and slide more easily. It is suggested, but not proven, that this effect could provide sufficient instability to trigger a surge. During such a surge further generation of heat would take place and a layer ... possibly several tens of meters in thickness could be raised to the melting point. After the surge, the glacier becomes stagnant and conduction of heat takes place in a static medium until the ice starts to flow slowly once again."

In this version a thick layer of warm ice is assumed to form during the surge so advection does not help to stop the surge-presumably it stops for mechanical reasons.

Although ice does deform more readily with increasing temperature, the required conditions for onset of creep instability are probably seldom met in glaciers (Nye, 1971). This does not appear to be a telling criticism of the thermal instability hypothesis because there are several other ways by which the bed of a cold glacier can attain the melting point. Surface accumulation and compressive flow both cause a glacier to thicken and have the effect of warming the bed by removing the cold surface boundary from it. These processes were used by Hoffmann and Clarke (1973) in their numerical model of the thermal instability mechanism and self-heating was neglected entirely. 
The aims of this paper are to summarize thermal regime information from surge-type glaciers, propose a thermal instability mechanism to explain surges of cold glaciers, describe the results of several computational experiments, and consider how well the thermal instability hypothesis can account for the known features of surging glaciers.

\section{Characteristics of surging glaciers}

In their review of the characteristics of surging glaciers Meier and Post ( 1969) include the following observations:

(I) "All surging glaciers surge repeatedly" with an apparently periodic surge cycle which is relatively constant for any given glacier.*

(2) The active surge phase commonly lasts $2-3$ years followed by a quiescent phase of approximately 15 to over 100 years with a common range of $20-30$ years. value.

(3) During the active phase, the flow velocity increases to at least ten times its quiescent

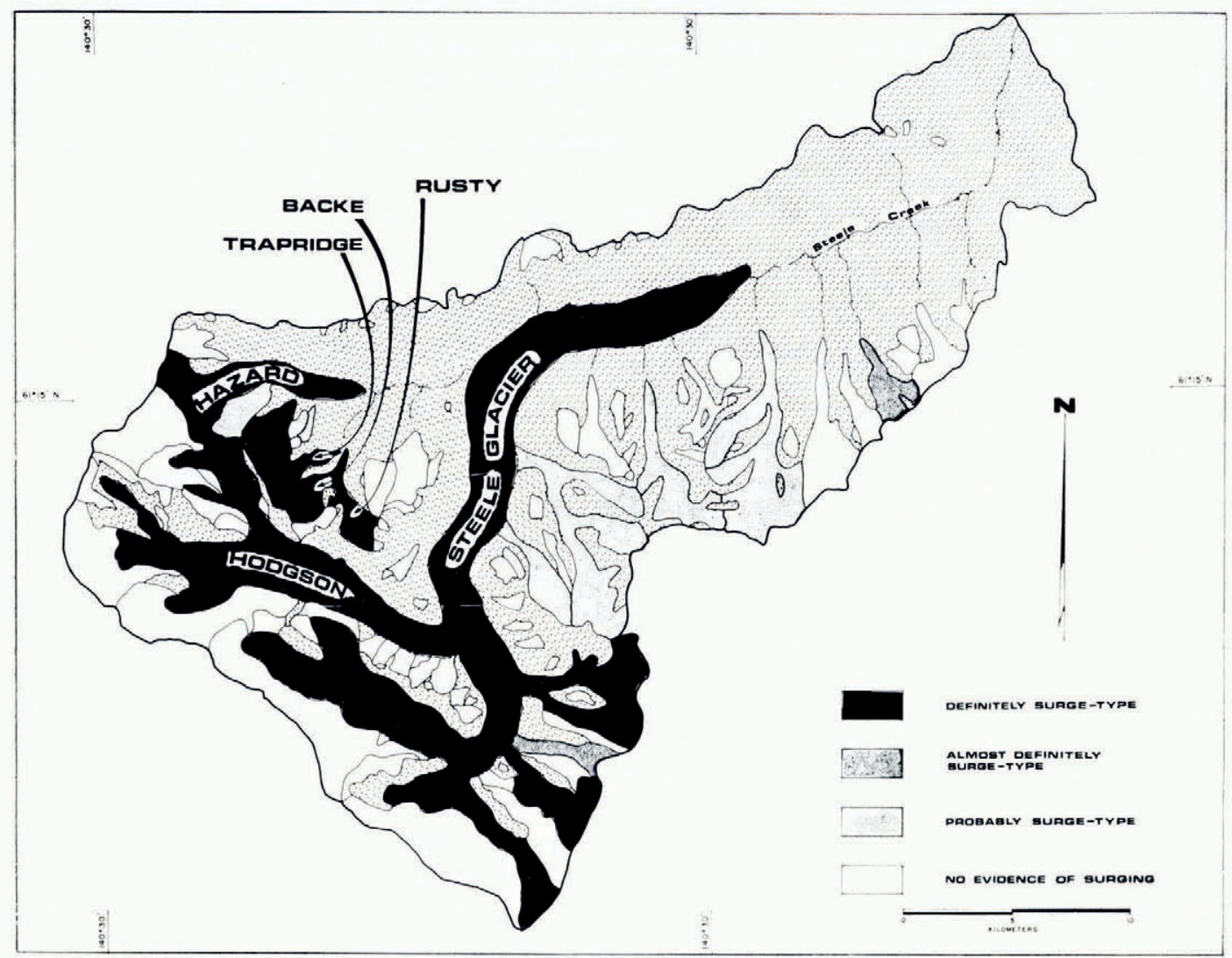

Fig. I. Surge-type glaciers in the Steele Creek basin, Yukon Territory, Canada (after Ragle and others, unpublished). The shading indicates the probability that a glacier is of surge type. Darkest shading denotes a glacier which definitely surges; lightest shading denotes a glacier which probably surges. Unshaded glaciers show no sign of surge behavior.

* Recent observations indicate that this is an over-simplification. Normal and surge-type glaciers do not form distinct classes and a continuous spectrum of behavior between these extremes is possible (personal communication from M. F. Meier). 
(4) "Glacier surges occur in almost all climatic environments. . . Marine, temperate glaciers in areas of high accumulation and ablation activity as well as subpolar glaciers in continental, cold areas can surge."

(5) The geographic distribution of surging glaciers is not random. In North America, all but a few surging glaciers are located in a relatively small area near the Alaska-Yukon border and none are found in the Brooks Range, Kenai Mountains, west and central Chugach Mountains, west and central Wrangell Mountains, Coast Mountains, Rocky Mountains, Cascade Range, Olympic Mountains, or Sierra Nevada (Post, r969). (A good example of the non-random distribution of surge-type glaciers is the remarkable concentration in the Steele Creek basin, Yukon Territory (Fig. I).)

An important corollary of the hypothesis that surging is thermally controlled is that temperate glaciers cannot surge by this mechanism. The statement "temperate glaciers ... can surge" therefore demands special attention, for if temperate glaciers do surge one of the following statements must be true:

(I) No glaciers surge by thermal instability.

(2) There are several surge mechanisms one of which could be thermal instability.

When Meier and Post asserted that temperate glaciers surge, their claim was based, not on direct temperature measurements, but on the fact that some surge-type glaciers are located in temperate marine environments. In recent years more geophysical data have become available and these results are summarized in Table I. Because so few temperature measurements have been taken in surge-type glaciers, seismic and radar sounding results are also useful in distinguishing between temperate and cold ice, although these indirect determinations should be viewed with a critical eye. It is a well-known fact that seismic P-wave velocity decreases as the melting point of ice is approached (Robin, I958) and velocities of $365^{\circ} \mathrm{m} \mathrm{s}^{-1}$ or less are characteristic of temperate ice. Seismic velocity measurements therefore give bulk temperature information. Attempts to sound temperate ice masses using pulsed radar systems operating in the frequency range $35-620 \mathrm{MHz}$ have not met with notable success and we take the successful completion of a radar-echo survey in this frequency range as evidence that a glacier is predominantly cold. A major drawback of using shallow ice temperature measurements, seismic refraction, and radar sounding to detect cold ice is that they cannot rule out the presence of an extensive layer of temperate ice at the bed, and it is the bottom regime which is critical to surging. Finally, the thermal regimes of surge-type glaciers may be sufficiently complex that they cannot be satisfactorily determined by one or two measurements.

At least three surging glaciers listed in Table I, the Kolka, Black Rapids and Variegated, are probably temperate so it appears that all surges cannot be thermally controlled. These determinations are based on a small number of shallow ice or firn temperature measurements, so are not definitive. The thermal regimes of surging outlet glaciers from Vatnajökull have not been measured; the characterization of Vatnajökull as temperate is based on measurements in the accumulation zone and these may be misleading. Possibly parts of these glaciers are not temperate in which case a thermal mechanism is still admissible.

Even if it is true that no glaciers surge by thermal instability there are many cold glaciers which surge and for these glaciers thermal processes must influence the timing of the surge cycle - a surging glacier cannot be frozen to a large fraction of its bed during a surge advance. We shall therefore continue our discussion of thermal control along two separate lines:

(I) To examine whether thermal instability can account for surge behavior in cold glaciers.

(2) To examine the thermal effects of surging on cold glaciers. A necessary condition for a glacier to surge is that much of its bed be at the melting point. If the deep temperature of a cold glacier alternates between periods when the bed is mainly cold and when it is mainly temperate, surges are likely to be thermally regulated. 
TAble I. Apparent thermal Regimes of SOME SURge-type glaciers

\begin{tabular}{|c|c|c|c|c|}
\hline $\begin{array}{l}\text { Glacier } \\
\text { or } \\
\text { ice sheet }\end{array}$ & Location & $\begin{array}{c}\text { Measurement } \\
\text { type }\end{array}$ & $\begin{array}{l}\text { Apparent } \\
\text { thermal } \\
\text { regime }\end{array}$ & References \\
\hline Kolka & U.S.S.R. & Io $\mathrm{m}$ temperature & Temperate & $\begin{array}{l}\text { Personal communication from V. M. } \\
\text { Kotlyakov }\end{array}$ \\
\hline Black Rapids & Alaska & Io $\mathrm{m}$ temperature & Temperate & Harrison and others (1975) \\
\hline Variegated & Alaska & Firn temperature & Temperate & $\begin{array}{l}\text { Bindschadler and others (unpublished); } \\
\text { Harrison (1972) }\end{array}$ \\
\hline Rusty & Yukon & $\begin{array}{l}\text { Deep temperature; } \\
620 \mathrm{MHz} \text { radar }\end{array}$ & Cold & $\begin{array}{l}\text { Classen and Clarke (1971); Clarke and } \\
\text { Goodman (1975) }\end{array}$ \\
\hline Trapridge & Yukon & $\begin{array}{l}\text { Deep temperature; } \\
620 \mathrm{MHz} \text { radar }\end{array}$ & Cold & $\begin{array}{l}\text { Goodman and others (1975); Jarvis and } \\
\text { Clarke (1975) }\end{array}$ \\
\hline Steele & Yukon & Deep temperature & Cold & $\begin{array}{l}\text { Jarvis and Clarke (1974); Clarke and } \\
\text { Jarvis (1976) }\end{array}$ \\
\hline Otto & Ellesmere Island & $35 \mathrm{MHz}$ radar & Cold & $\begin{array}{l}\text { Hattersley-Smith (1964, 1969); Evans } \\
\text { and Robin (1966) }\end{array}$ \\
\hline Roslin & Staunings Alper & $\begin{array}{l}9 \mathrm{~m} \text { temperature; } \\
440 \mathrm{MHz} \text { radar }\end{array}$ & Cold & $\begin{array}{l}\text { Davis and others (1973); Miller (un- } \\
\text { published) }\end{array}$ \\
\hline Bråsvellbreen & Nordaustlandet & $25 \mathrm{~m}$ temperature & Cold & Thompson (1953) \\
\hline Vatnajökull & Iceland & $\begin{array}{l}30 \mathrm{~m} \text { temperature; } \\
\mathrm{P} \text {-wave velocity }\end{array}$ & Temperate & $\begin{array}{l}\text { Joset and Holtzscherer (1954); Bauer } \\
\text { (1955); Rist (1961); Thorarinsson } \\
\text { (1964, 1969) }\end{array}$ \\
\hline Barnes* & Baffin Island & $\begin{array}{r}20 \mathrm{~m} \text { temperature; } \\
35 \mathrm{MHz} \text { radar; } \\
620 \mathrm{MHz} \text { radar }\end{array}$ & Cold & $\begin{array}{l}\text { Ward (1952); Ward and Orvig (1953); } \\
\text { Løken (1969); Jones (1972); Holds- } \\
\text { worth (1973[a], [b]); personal com- } \\
\text { munication from R. A. O'Neil }\end{array}$ \\
\hline Antarctic* & & $\begin{array}{l}\text { Deep temperature; } \\
\text { P-wave velocity; } \\
\text { radar }\end{array}$ & Cold & Many authors \\
\hline
\end{tabular}

* May not surge.

\section{Cold surge-type glaciers}

Only two cold surge-type glaciers, the Rusty and Trapridge in the Yukon Territory, have a reasonably well-known thermal structure. Both glaciers are small but 15 other surge-type glaciers, spanning a wide range of sizes, lie in the immediate vicinity (Fig. I) so it is reasonable to suppose that all these glaciers surge by the same mechanism.

The main features of the thermal regimes of Rusty and Trapridge Glaciers are that substantial portions of the beds are at or near the melting point and the glacier snouts appear to be frozen to the beds (Fig. 2a). This situation is similar to the "cold ring" structure which Schytt (I969) noted in the surge-type ice caps of Svalbard, although in that case temperate ice was held in by a ring of cold ice (Fig. 2b).

The model of thermal instability in cold glaciers which we shall now consider in mathematical detail closely resembles that originally proposed by Robin (I955). The surge starts when the basal ice temperature reaches the melting point. Upon the onset of basal melting the thermal boundary condition at the ice-rock interface changes from continuity of flux to a fixed temperature at the interface and discontinuous flux. Two competing processes control the duration of the sliding phase: frictional heat melts water at the ice-rock interface and sustains the surge, but the extension of the glacier as it advances causes the basal ice temperature gradient to increase. Eventually thermal flux away from the ice-rock interface exceeds 

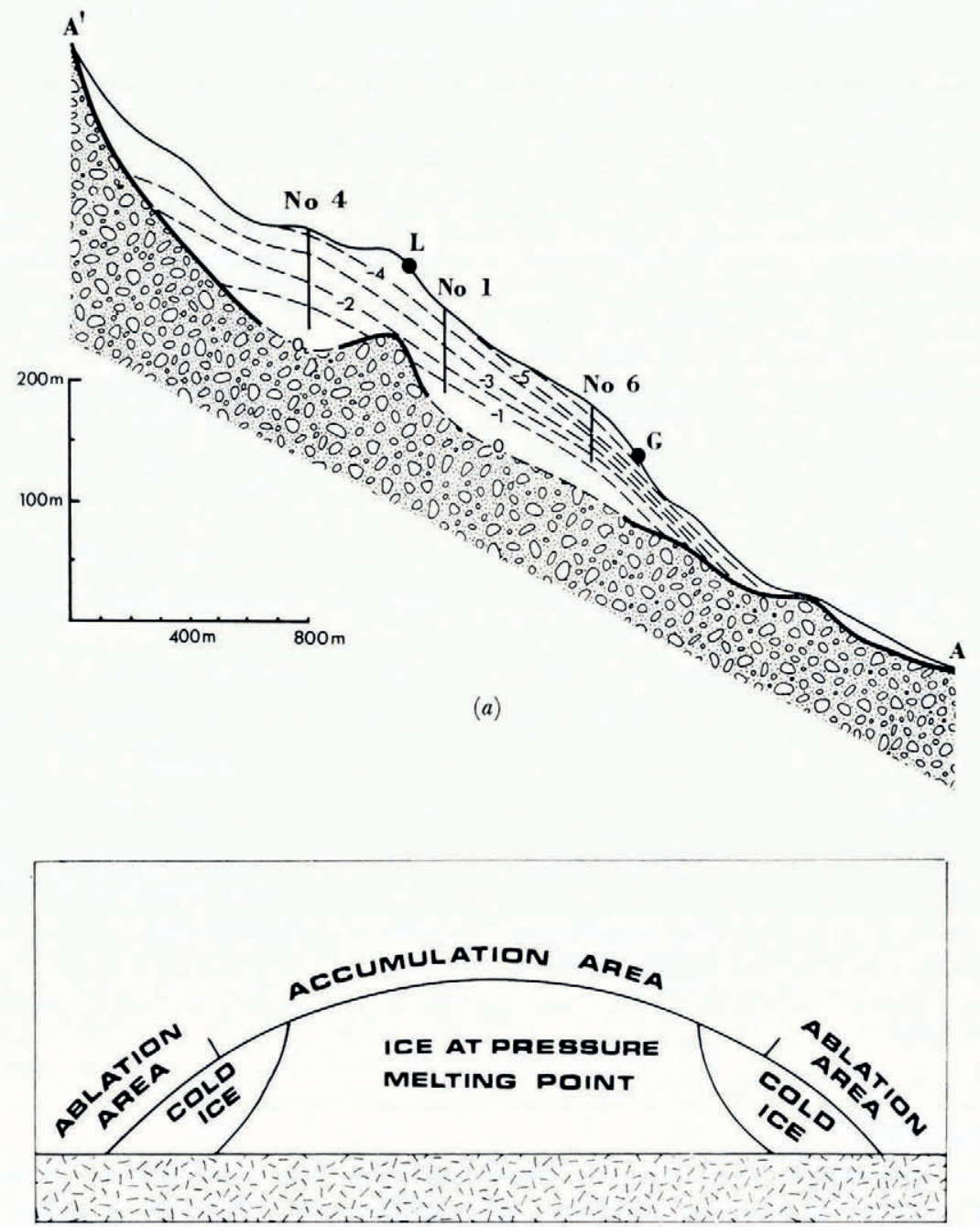

(b)

Fig. 2. a. The thermal regime of Trapridge Glacier. Drilling sites and maximum drilling depths are indicated by vertical lines. Depth to bedrock was found by radar sounding. b. The "cold ring" thermal regime of ice caps in Nordaustlandet (after Schytt, 1969).

the frictional heat generation and the glacier refreezes to its bed. A quiescent period follows until the combined effects of surface accumulation and compressive glacier flow cause the bed temperature to return to the melting point. When certain conditions on the ice thickness, the surface temperature, and the geothermal flux are satisfied, a periodic cycle of advance and quiescence results.

There is disagreement over whether a finite thickness of temperate basal ice must form before sliding can occur (Weertman, 1967; Lliboutry, 1967). For simplicity we assume that a temperate layer is not required, but it would be quite possible to develop an analogous model of thermal instability based on changes in thickness of a temperate basal layer. 


\section{SumMARY OF SYMBOLS}

$A$ deformational heat generation rate per unit volume

$B$ flow-law coefficient

$b$ mass-balance function

$c_{0}$ pressure-melting coefficient

$D_{0}$ constant coefficient of simplified sliding law

$D_{\mathrm{I}}$ quantity from Weertman's sliding theory which depends on basal shear stress and bed roughness

$D_{2}$ quantity from Weertman's sliding theory which depends on basal shear stress and bed roughness

$E$ creep activation energy of ice

$G$ geothermal flux normal to the bed

$g$ gravitational acceleration

$h$ thickness of basal water film

$h^{\prime}$ critical thickness of basal water film

$K_{1}$ thermal conductivity of rock

$K_{2}$ thermal conductivity of ice

$L$ latent energy of fusion for ice

$n$ flow-law exponent

$Q$ total volume flux of ice per unit width

$Q_{\mathrm{i}}$ internal creep contribution to volume flux of ice per unit width

$Q_{0} \quad$ volume flux of ice per unit width at $x=0$

$q$ volume flux of water per unit width

$R$ gas constant

$T_{\mathrm{I}}$ temperature in rock

$T_{2}$ temperature in ice

$T_{\mathrm{m}}$ the melting temperature of ice

$T_{\mathrm{s}}$ surface temperature

$T_{i, j}{ }^{n}$ temperature at the mesh point $(i, j)$ evaluated at the $n$th time step

$t$ time

$U \quad x$ component of velocity field in ice

$U_{\mathrm{b}}$ glacier sliding velocity

$U_{0}$ velocity of glacier snout

$u$ velocity of water flow averaged in the $z$ direction

$V_{\mathbf{Q}}$ rate at which ice thickens due to compression during quiescent phase

$V \quad y$ component of velocity field in ice

$W$ rate of melting or refreezing at glacier bed

$X$ length of active zone

$x$ longitudinal space coordinate

$r$ glacier thickness measured normal to the bed

$y$ space coordinate normal to the glacier bed

$\alpha$ surface slope

$\beta$ bed slope

$\eta$ viscosity of water

$\kappa_{\mathrm{I}}$ thermal diffusivity of rock

$\kappa_{2}$ thermal diffusivity of ice

$\lambda$ dimensionless finite-difference parameter $=\kappa \Delta t /(\Delta y)^{2}$

$\nu$ exponent of simplified sliding law

$\rho$ density of ice

$\sigma_{x x}{ }^{\prime} \quad$ longitudinal deviatoric stress 
$\begin{aligned} \sigma_{y y}{ }^{\prime} & \text { deviatoric stress normal to the bed } \\ \sigma_{x y} & \text { shear stress } \\ \tau & \text { basal shear stress }\end{aligned}$

\section{Mathematical MOdel}

Four sets of equations describe the physical basis of the thermal instability surge mechanism. These are the equations of heat conduction, sliding, water production and water flow. For simplicity we shall assume that the glacier bed is a plane inclined at an angle $\beta$ with respect to the horizontal and that the $x$-axis runs parallel to the bed; the $y$-axis is directed perpendicular to the bed surface. The origin of coordinates is taken at the start of the "active zone", that is the zone participating in the surge; for some glaciers the entire glacier forms the active zone (Meier and Post, r 969 ). Figure 3 shows the coordinate system used.

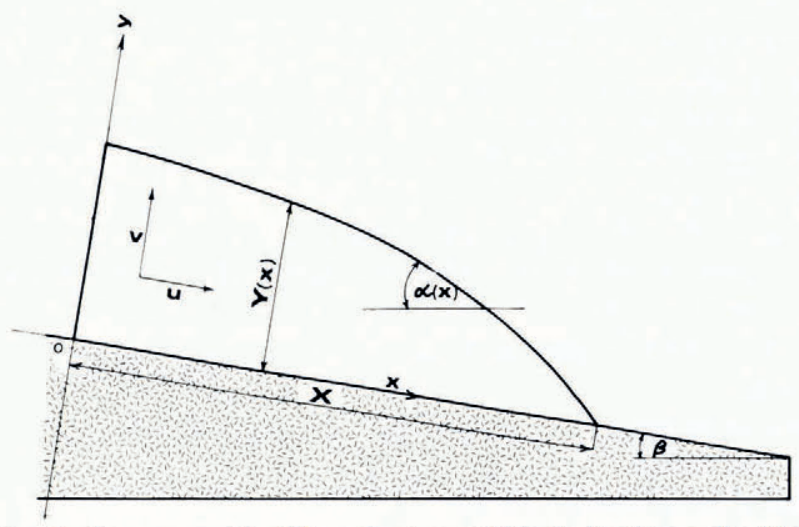

Fig. 3. The coordinate system for the surge model. The region $0 \leqslant x \leqslant X$ is the "active zone" which participates in the surge; the volume flux of ice at the boundary between the active and inactive zones $(x=o)$ is assumed to remain constant throughout the surge cycle.

\section{Heat conduction equations}

The equations of heat conduction in bedrock and glacier ice for two-dimensional flow are

$$
\begin{gathered}
\frac{\partial^{2} T_{1}}{\partial x^{2}}+\frac{\partial^{2} T_{1}}{\partial y^{2}}=\frac{\mathrm{I}}{\kappa_{1}} \frac{\partial T_{1}}{\partial t}, \\
\frac{\partial^{2} T_{2}}{\partial x^{2}}+\frac{\partial^{2} T_{2}}{\partial y^{2}}=\frac{\mathrm{I}}{\kappa_{2}} \frac{\partial T_{2}}{\partial t}+\frac{U}{\kappa_{2}} \frac{\partial T_{2}}{\partial x}+\frac{V}{\kappa_{2}} \frac{\partial T_{2}}{\partial y}-\frac{A}{\kappa_{2}},
\end{gathered}
$$

(see Carslaw and Jaeger, I959, ch. I). For a material satisfying Glen's flow law

$$
A=2 B_{0} \exp (-E / R T)\left[\frac{1}{2}\left(\sigma_{x x^{\prime 2}}+\sigma_{y y^{\prime 2}}\right)+\sigma_{x y^{2}}\right]^{n+1 / 2}
$$

where $B_{0}=B\left(T_{0}\right) \exp \left(E / R T_{0}\right)$ and $T_{0}=273 \mathrm{~K}$. The justification for neglecting all thermal effects due to water flow through the glacier in Equation (2) is that the glacier is assumed to be cold so that an extensive internal drainage system is unlikely to form. If this assumption is untrue, prior knowledge of the nature and extent of the internal drainage system would be required to correct for the transport of heat by water flow.

The boundary condition at the ice-rock interface takes one of two forms. If the temperature at the interface is below the melting point, no melting occurs at the interface and the thermal flux from the bed is exactly equal to the flux into the bottom ice; thus 


$$
\kappa_{1} \frac{\partial T_{1}}{\partial y}=K_{2} \frac{\partial T_{2}}{\partial y}
$$

at the boundary. If the bed is at the melting point the boundary condition changes to $T_{1}=T_{2}=T_{\mathrm{m}}$. When the bed is at the melting point the flux may become discontinuous at the boundary and any imbalance is accounted for by melting basal ice or freezing basal water. This change in boundary condition plays an important role in the thermal control of surging.

\section{Equations of motion}

A completely rigorous model of glacier surging would require a solution of equations for creep motion together with a realistic sliding law. For several reasons this is not a practical course to follow. At the present time it is probably not computationally feasible to solve the full equations of motion for a glacier, so one must settle for approximate flow solutions. The sliding law, and especially the lubricating effect of basal water, is still a matter of great uncertainty and until some general agreement is reached there seems little point in adding unnecessary complexity to surge models. But until the shortcomings of sliding theory are removed no complete theory of surging can be constructed.

The use of specific approximations to the flow and sliding equations will be described in greater detail in the section on numerical modelling.

\section{Water generation}

Sliding at the bed creates frictional heat at a rate proportional to $U_{\mathrm{b}} \tau$. The rate of melting from the glacier bottom is

$$
W=\frac{\mathbf{I}}{\rho L}\left[U_{\mathrm{b}} \tau+K_{2} \frac{\partial T_{2}}{\partial y}-K_{\mathrm{I}} \frac{\partial \mathcal{T}_{\mathrm{I}}}{\partial y}\right]
$$

where the temperature derivatives are taken at the ice-rock interface. This expression is a straightforward generalization of an equation given by Weertman (I962), and is true regardless of the sliding law. It is assumed that because the glacier is cold, water from the surface does not reach the bed.

\section{Basal water flow}

The rate of sliding is dependent on the amount of water at the glacier bed which in turn depends on the rate of water production and the rate at which water flows from the bed. The principle of conservation of water volume gives the continuity equation

$$
\frac{\partial q}{\partial x}+\frac{\partial h}{\partial t}=W
$$

(Weertman, I962) where

$$
q=\int_{0}^{h} u \mathrm{~d} y
$$

$u(x, y, t)$ is the water flow velocity at the bed averaged across the width of the glacier.

Before one can solve Equation (6) it is necessary to introduce an equation of state $q=q(h)$ relating $q$ to the mean thickness of basal water. Unfortunately the form of this equation is a matter of current disagreement. If basal water flows as if between two parallel plates separated by a distance $h$ and inclined at an angle $\delta$

$$
q=\frac{\rho g h^{3} \sin \delta}{\mathrm{I} 2 \eta} .
$$


This form for the equation of state was proposed by Weertman (1962) and later, modified to allow for a generalized pressure gradient, defended by him on theoretical grounds (Weertman, 1972). If water does not flow as a sheet some other form of the equation of state must replace Equation (8).

\section{Numerical MODELLING}

Two different numerical models of cyclic surging in cold glaciers will be described. The first model is essentially a kinematic one - a simplified velocity field is assumed and the temperature equations are solved. The glacier sliding velocity is taken to depend in a very simple way on the mean thickness of water at the bed. In the second model the glacier motion is approximated by a kinematic wave equation and from the time evolution of the glacier profile approximations to the velocity fields $U$ and $V$ are calculated. For this model the sliding is introduced artificially and the distribution of sliding velocity over the active zone is taken to be a simple expression.

The aims of the two models are quite different. The first is intended to demonstrate that cyclic surges can be explained by thermal instability provided the sliding law is strongly dependent on the amount of water at the bed. In the second a constant surge cycle is assumed and the thermal effects of surging, irrespective of the underlying mechanism, are studied.

\section{Finite-difference scheme}

Because longitudinal temperature gradients in glaciers are usually small in comparison to those measured perpendicular to the bed the longitudinal heat conduction can be neglected so that the ice temperature equation becomes

$$
\frac{\partial^{2} T_{2}}{\partial y^{2}}=\frac{\mathrm{I}}{\kappa_{2}} \frac{\partial T_{2}}{\partial t}+\frac{U}{\kappa_{2}} \frac{\partial T_{2}}{\partial x}+\frac{V}{\kappa_{2}} \frac{\partial T_{2}}{\partial y}-\frac{A}{K_{2}}
$$

(Paterson, I969, p. I 80). To write Equation (9) as a finite-difference equation we first replace the variables $x, y$, and $t$ by the discrete variables $i \Delta x, j \Delta y$ and $n \Delta t$ where the indices take integer values; $\mathcal{T}_{i, j^{n}}$ therefore represents the temperature at the mesh point $(i, j)$ evaluated at the $n$th time step. Following a partially implicit numerical scheme, we write

$$
\begin{aligned}
-\lambda T_{i, j-1}^{n+1}+(\mathrm{I}+2 \lambda) & T_{i, j}{ }^{n+1}-\lambda T_{i, j+1}^{n+1} \\
= & T_{i, j}{ }^{n}-\frac{\Delta t}{2 \Delta x} U_{i, j}{ }^{n}\left(T_{i+1}, j^{n}-T_{i-1, j}{ }^{n}\right)- \\
& \quad-\frac{\Delta t}{2 \Delta y} V_{i, j}{ }^{n}\left(T_{i, j+1}^{n}-T_{i, j-1}{ }^{n}\right)+\frac{\kappa \Delta t}{K} A_{i, j}{ }^{n}
\end{aligned}
$$

where $\lambda=\kappa \Delta t /(\Delta y)^{2}$ is a dimensionless quantity. For $U_{i, j} n=V_{i, j}{ }^{n}=A_{i, j}{ }^{n}=0$ we obtain the form of the difference equations in rock. At the $n$th time step all quantities on the right-hand side are known and the unknowns are the temperatures at the $(n+\mathrm{I})$ th time step. These can be computed by solving a system of tridiagonal equations obtained from Equation ( Io) and the boundary conditions. Carnahan and others (1969) give a clear account of the solution of tridiagonal systems; a comprehensive discussion of finite-difference methods can be found in Forsythe and Wasow (1960).

\section{Stretched slab model}

The aim of the approximations which lead to the stretched slab model is to eliminate $x$ dependence from the temperature equations and to obtain a very simple velocity distribution. An earlier version of this model (Hoffmann and Clarke, 1973) suffered from lack of generality and a computational error. 


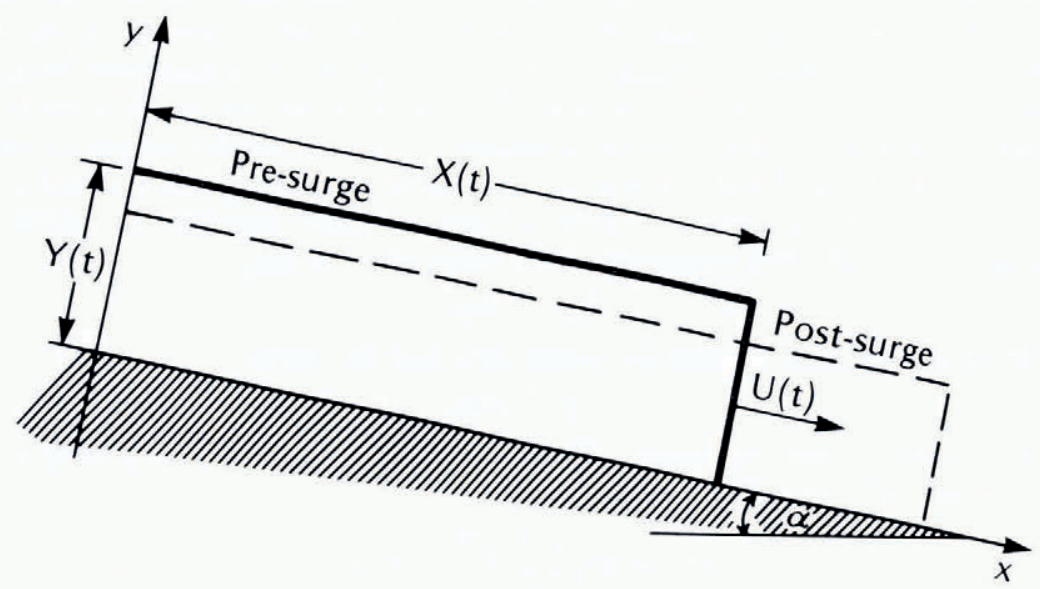

Fig. 4. The "stretched slab" model of surging.

Let us represent a surge-type glacier by an inclined slab truncated at $x=X$ and attached to immobile ice or rock at $x=0$; thus $0 \leqslant x \leqslant X$ represents the "active zone" (Fig. 4). The upper surface of the slab $y=Y(t)$ is held at a constant temperature $T_{\mathrm{s}}$ and the thickness of the glacier changes in response to accumulation at the surface and motion of the slab. When the snout advances during a surge, the glacier thins: during the quiescent phase it thickens. Because the creep contribution to the flow is small compared to the sliding contribution, we neglect it entirely during the surge and assume that the forward ice velocity is given by the sliding rate which is taken to vary linearly with distance from the snout so that

$$
U(x, y)=U_{\mathrm{b}}(x)=x U_{\mathrm{o}} / X
$$

where $U_{0}$ is the snout velocity. During an advance the active zone is consequently under uniform tension, and the vertical component of velocity is

$$
V(y)=y V_{0} / r+W
$$

where $V_{0}=-r U_{0} / X$ is the rate at which the glacier changes thickness due to extension and $W$ is the rate at which basal melting removes ice from the bed. During quiescence the glacier is assumed to thicken due to a uniform compressive strain-rate $V_{\mathbf{Q}} / \Upsilon$. The shearing contribution to the flow is neglected though not its effect on internal heat generation.

If the water production does not vary rapidly on the time-scale of hours the basal water flow will be steady and

$$
\frac{\partial q}{\partial x} \approx W
$$

giving

$$
q(x, t)=\frac{\mathrm{I}}{\rho L}\left\{\frac{U_{0} \tau x^{2}}{2 X}+x\left[K_{2} \frac{\partial T_{2}}{\partial y}-K_{\mathrm{I}} \frac{\partial T_{\mathrm{I}}}{\partial y}\right]\right\} .
$$

By assuming a relationship between $q$ and $h$ such as Equation (8) the thickness of the basal water film could be determined and from that the sliding rate found.

We have done this for Weertman's sliding laws

$$
\begin{array}{ll}
U_{\mathbf{b}}=D_{\mathrm{I}} & h \leqslant h^{\prime}, \\
U_{\mathbf{b}}=D_{2} h & h>h^{\prime},
\end{array}
$$


(Weertman, 1962, 1969) and water-flow equation (8) and find that unreasonably smooth beds must be assumed before satisfactory surge velocities are achieved. It is, in part, this difficulty that led Robin and Weertman (1973) to propose stress-dammed basal water flow as a cause of surges. Apart from their lack of plausibility, very smooth beds make the friction term overwhelm the conduction term in Equation (5) so the model surges do not stop.

Owing to the uncertainties in the sliding and water-flow equations a simplified approach is followed. The two equations are combined into a single equation to which no physical interpretation is ascribed. We assume that for lubricated sliding

$$
U_{\mathrm{b}}=D_{3} h \gamma
$$

and that a general equation of state for water flow has the form

$$
q=D_{4} h^{5}
$$

where $D_{3}, D_{4}, \gamma$ and $\xi$ are constants. For Weertman's theories $\gamma=\mathrm{I}$ and $\xi=3$. Thus Equations ( 17 ) and ( 18 ) combine to give

$$
U_{\mathbf{b}}=D_{3}\left(\frac{q}{D_{4}}\right)^{\gamma / \xi} \equiv D_{0} q^{\nu}
$$

Certain choices of the parameters $D_{0}$ and $\nu$ were found to give acceptable results. The sliding velocity computed in this way was taken as the velocity at $x=X / 2$ and the velocity was taken

\begin{tabular}{|c|c|c|}
\hline \multicolumn{3}{|l|}{ Model parameters } \\
\hline Surface slope & $\alpha$ & $10.8^{\circ}$ \\
\hline Surface temperature & $T_{\mathrm{s}}$ & $-4.5^{\circ} \mathrm{C}$ \\
\hline $\begin{array}{l}\text { Geothermal flux (normal to } \\
\text { bed) }\end{array}$ & $G$ & $0.131 \mathrm{~W} \mathrm{~m}^{-2}\left(3.125 \mu \mathrm{cal} \mathrm{cm} \mathrm{cm}^{-2} \mathrm{~s}^{-1}\right)$ \\
\hline Surface accumulation rate & $b$ & $0.1 \mathrm{~m} \mathrm{a}^{-1}$ \\
\hline $\begin{array}{l}\text { Rate at which ice thickens due } \\
\text { to compression in quiescence }\end{array}$ & $V_{\mathbf{Q}}$ & $0.4 \mathrm{~m} \mathrm{a}^{-1}$ \\
\hline Sliding law & $U_{\mathrm{b}}$ & $D_{0} q^{\nu}$ \\
\hline Sliding parameter & $\nu$ & $2 / 3$ \\
\hline Sliding parameter & $D_{0}$ & $2.24 \times 10^{7} \mathrm{~m}^{-1 / 3} \mathrm{a}^{-1 / 3}$ \\
\hline \multicolumn{3}{|l|}{ Physical constants } \\
\hline Density of ice & $\rho$ & $900 \mathrm{~kg} \mathrm{~m}^{-3}$ \\
\hline Flow-law coefficient & $B$ & $0.038 \mathrm{bar}^{-n} \mathrm{a}^{-1}$ \\
\hline Flow-law exponent & $n$ & 3.07 \\
\hline Thermal conductivity of bed & $\ddot{K}_{\mathrm{I}}$ & 2.1 $\mathrm{W} \mathrm{m}^{-1} \mathrm{deg}^{-1}$ \\
\hline Thermal conductivity of ice & $\kappa_{2}$ & 2.1 $\mathrm{W} \mathrm{m}^{-1} \mathrm{deg}^{-1}$ \\
\hline Thermal diffusivity of bed & $\kappa_{\mathrm{I}}$ & $10^{-6} \mathrm{~m}^{2} \mathrm{~s}^{-2}$ \\
\hline Thermal diffusivity of ice & $\kappa_{2}$ & $10^{-6} \mathrm{~m}^{2} \mathrm{~s}^{-2}$ \\
\hline Creep activation energy of ice & $E$ & $58.5 \times 10^{3} \mathrm{~J} \mathrm{~mol}^{-1}\left(14 \mathrm{kcal} \mathrm{mol}^{-1}\right)$ \\
\hline Pressure melting coefficient & $c_{0}$ & -0.0074 deg bar $^{-1}$ \\
\hline \multicolumn{3}{|l|}{ Finite difference variables } \\
\hline Spatial increment & $\Delta y$ & $1.0 \mathrm{~m}$ \\
\hline Time increment & & \\
\hline During surge phase & $\Delta t_{\mathrm{s}}$ & O. I a \\
\hline During quiescent phase & $\Delta t_{\mathrm{Q}}$ & I.0 a \\
\hline \multicolumn{3}{|l|}{ Model outputs } \\
\hline Duration of surge phase & & $6.0 \mathrm{a}$ \\
\hline Duration of quiescent phase & & $34.0 \mathrm{a}$ \\
\hline Snout displacement & & $696.0 \mathrm{~m}$ \\
\hline Average velocity during surge & & $116.0 \mathrm{~m} \mathrm{a}^{-1}$ \\
\hline $\begin{array}{l}\text { Pre-surge ice thickness (mea- } \\
\text { sured normal to bed) }\end{array}$ & & $80.0 \mathrm{~m}$ \\
\hline $\begin{array}{l}\text { Post-surge ice thickness (mea- } \\
\text { sured normal to bed) }\end{array}$ & & $63.0 \mathrm{~m}$ \\
\hline
\end{tabular}
to vary linearly between $x=0$ and the snout at $x=X$ according to Equation (I I ).

Table II. Trapridge Glacier Model A 
Model computations are carried out in the following manner: The surface temperature, geothermal flux, initial thickness, initial length, accumulation rate, and rate at which compressive flow raises the ice surface during the quiescent phase, and a sliding rule of the form of Equation (19) are chosen, and physical constants such as the flow-law coefficient and exponent (used in computing the deformational self-heating but not the actual flow) and the thermal properties of ice and rock assigned. If the bed is at the pressure-melting temperature sliding begins and the water flow rate at $x=X / 2$ is calculated from Equation (14). Sliding continues at a rate determined by Equations (14) and (19) and the slab stretches and thins until conduction losses into the bottom ice cause the water layer to disappear and sliding to stop. Throughout the quiescent phase the glacier thickens due to the combined effects of surface accumulation and compressive flow until the bed returns to the melting point and a new surge cycle begins. The ice thickness, intensity, and duration of surges, and the length of quiescence, are allowed to adjust freely to the steady surface accumulation rate and the compressive thickening during quiescence. After 25 or more cycles the temperature distribution, thickness, and rate of advance become perfectly periodic.

\section{Discussion of stretched slab modelling results}

A model of cyclic surges for Trapridge Glacier was constructed using data extracted from Sharp (1947, I951), Collins (1972), Goodman and others (1975), and Jarvis and Clarke (1975). The principal model inputs and outputs are given in Table II and the computed pre-surge and post-surge temperature distributions in ice and rock are presented in Figure 5 .

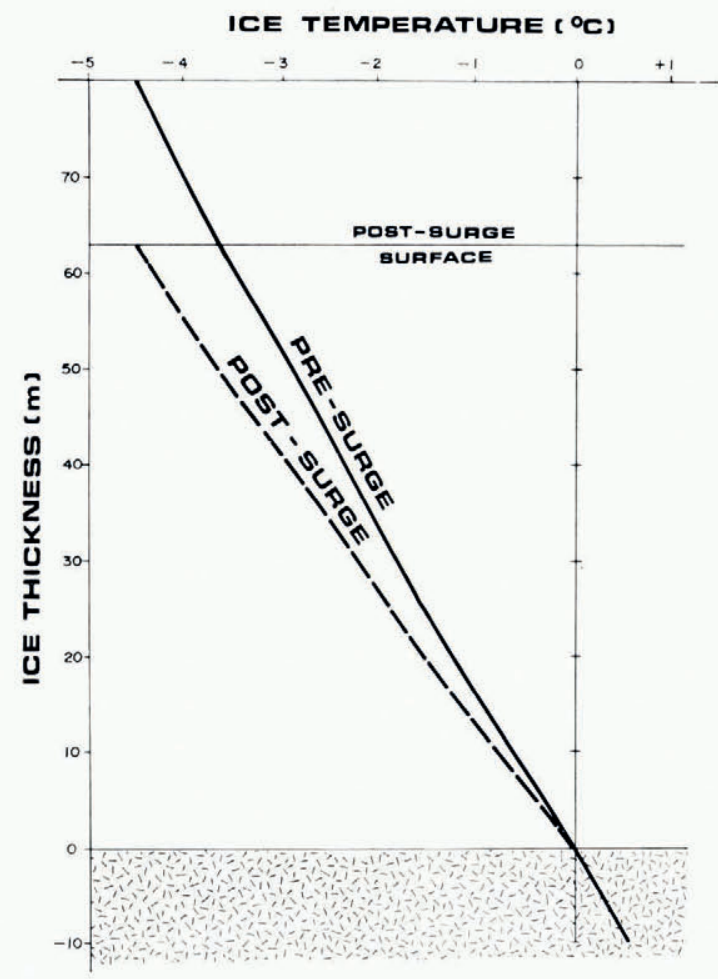

Fig. 5. Pre-surge and post-surge temperature distribution computed for Trapridge Glacier Model A. For this calculation the thermal conductivities of ice and rock have been taken as equal. 
As the duration and intensity of the surge is largely determined by the non-physical parameters $D_{0}$ and $\nu$ while the duration of quiescence depends on the ill-determined upward rate of surface movement during the post-surge recovery, the 40 year surge cycle found for our Model A is not a reliable predictor of the actual periodicity for Trapridge surges.

\section{Two-dimensional model}

The purpose of the foregoing stretched-slab model was to demonstrate the possibility that thermal processes control the existence and thickness of the basal water layer in cold surgetype glaciers and may in this way determine the onset and termination of a surge advance. We shall now investigate the effects of cyclic surging on the temperature field within a cold glacier. In the following two-dimensional model we are not concerned with what actually drives the surge, but with the thermal consequences of surging. Instead of allowing the timing of the surge cycle and the ice displacement to be determined by processes at the glacier bed, we assume a fixed surge cycle with a constant snout velocity during each surge. The surface profile and temperature field are allowed to adjust to this forced cycle of surging and eventually become cyclic with time as well, losing all memory of the assumed initial conditions.

The conservation equation

$$
\frac{\partial Q}{\partial x}+\frac{\partial Y}{\partial t}=b
$$

governs the evolution of the surface profile where $Q$ the ice flux per unit width is given by

$$
Q=\int_{0}^{r} U(x, y, t) \mathrm{d} y
$$

(Lighthill and Whitham, I955; Weertman, 1958; Nye, 1958, I960; Whitham, 1974). Rather than solve the equations of motion to calculate $U$ and $V$ we make a simplifying approximation. A bulk flow law of the form

$$
Q_{i}=B \tau^{n} Y^{2}
$$

will be assumed to govern the creep flow contribution to the total flux where $\tau=\rho g \Upsilon \sin \alpha$. Equation (22) is an integrated form of Glen's power law and has been used extensively in modelling glacier flow (Nye, I96o, I963; Budd, I969, I975; Rasmussen and Campbell, 1973; Budd and McInnes, 1974). If we assume that ice flows in a columnar fashion so that $U$ varies with $x$ but not with $y$, we can calculate $U$ directly from $Q$ and avoid solving the complete equations of motion for $U$ and $V$. The velocity normal to the bed follows from the incompressibility of ice

$$
V(x, y)=-\int_{0}^{y} \frac{\partial U(x)}{\partial x} \mathrm{~d} y^{\prime}
$$

where we neglect the small velocity contribution due to bottom melting.

During the surge phase the glacier is assumed to flow by both sliding and internal deformation. We shall take the snout velocity $U_{0}$ as constant throughout the surge and assume that the sliding velocity varies over the active zone according to

$$
U_{\mathrm{b}}(x)=\frac{1}{2} U_{\mathrm{o}}[\mathrm{I}-\cos (\pi x / X)] .
$$

This expression is probably a fairly good approximation to the actual distribution averaged over the surge. The derivative $\partial U_{\mathrm{b}} / \partial x$ vanishes at $x=0$ to prevent a discontinuity in the strain-rate, and at $x=X$ so that the snout slides as a rigid block. Finally the choice of the form for $U_{\mathbf{b}}(x)$ greatly influences the pre-surge and post-surge profiles of a cyclically surging glacier. Equation (24) has proven to give acceptable results where other functions have 
yielded bizarre ones. If the bed near the snout is below the melting point just prior to a surge, Equation (24) requires that sliding can occur over a frozen bed. What actually happens in real surging glaciers with a cold snout is doubtless very complex. Ice may, perhaps, be thrust over a cold bed by shear, or basal water may be injected into the frozen zone to initiate sliding.

For the purposes of computing the velocity components $U$ and $V$ it is assumed that $U$ is independent of depth, but for the computation of the internal heat generation the thermal effects of the creep flow contribution are distributed over the thickness of the glacier according to the following procedure. The shear strain is taken as $\frac{1}{2} \partial U / \partial y=B \sigma_{x y}{ }^{n}$ and the second invariant of the strain-rate tensor constructed from the strain-rate components $\frac{1}{2} \partial U / \partial y$, $\partial U / \partial x$ and $\partial V / \partial y$. From this invariant the second invariant of the stress deviator

$$
\frac{1}{2}\left(\sigma_{x x^{\prime 2}}+\sigma_{y y}{ }^{\prime 2}\right)+\sigma_{x y^{2}}
$$

is formed and Equation (3) used to calculate the internal heating.

Apart from assumptions of physical constants such as gravity, density, thermal conductivity, diffusivity, etc., the basic inputs are the surface temperature distribution $T_{\mathrm{s}}(x)$, the mass-balance function $b(x)$, the geothermal flux $G$ (measured normal to the bed), and the duration of the surge and quiescent phases. Together with the assumed flow and sliding relations these determine the surface profile and temperature field. A constant ice flux $Q_{0}$ is assumed to feed ice into the active zone at $x=0$ and this together with the assumed initial profile give the required boundary and initial conditions for Equation (20). More complicated functional forms for $T_{\mathrm{s}}, b$ and $G$ involving dependence on time and the $y$ coordinate could easily be introduced.

To start the computations, an initial surface profile and temperature field are assumed and the surface profile, temperature, and velocity fields are then computed as the glacier model is forced through a number of surge cycles. The durations of the surge and quiescent phases

Table III. Numerical inputs for Trapridge Glacier Model. B

\begin{tabular}{|c|c|c|}
\hline \multicolumn{3}{|l|}{ Model parameters } \\
\hline Bed slope & $\beta$ & $10.0^{\circ}$ \\
\hline Ice flux into active zone & $Q_{0}$ & I $000 \mathrm{~m}^{2} \mathrm{a}^{-1}$ \\
\hline Duration of surge & $t_{\mathrm{s}}$ & $2.0 \mathrm{a}$ \\
\hline Duration of quiescence & $t_{\mathrm{Q}}$ & $35.0 \mathrm{a}$ \\
\hline Snout velocity during surge & $U_{0}$ & $250 \mathrm{~m} \mathrm{a}^{-1}$ \\
\hline $\begin{array}{l}\text { Geothermal flux (normal to } \\
\text { bed) }\end{array}$ & $G$ & 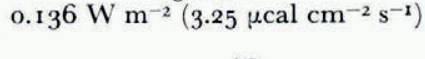 \\
\hline Surface temperature & $T_{\mathrm{s}}$ & $-4.5^{\circ} \mathrm{C}$ \\
\hline Mass-balance function & $b(x)$ & $(500-x) / 500 \mathrm{~m} \mathrm{a}^{-1}$ \\
\hline Basal-sliding function & $U_{\mathrm{b}}(x)$ & $U_{\mathrm{o}}[\mathrm{I}-\cos (\pi x / X)] / 2$ \\
\hline \multicolumn{3}{|l|}{ Physical constants } \\
\hline Density of ice & $\rho$ & $900 \mathrm{~kg} \mathrm{~m}^{-3}$ \\
\hline Flow law coefficient & $B$ & $0 . \mathrm{I} \mathrm{bar}^{-n} \mathrm{a}^{-1}$ \\
\hline Flow law exponent & $n$ & 3.0 \\
\hline Thermal conductivity of bed & $K_{\mathrm{I}}$ & 2.1 W m-1 $\mathrm{deg}^{-1}$ \\
\hline Thermal conductivity of ice & $K_{2}$ & 2.1 $\mathrm{W} \mathrm{m}^{-1} \mathrm{deg}^{-1}$ \\
\hline Thermal diffusivity of bed & $\kappa_{\mathrm{I}}$ & $10^{-6} \mathrm{~m}-\mathrm{s}^{-2}$ \\
\hline Thermal diffusivity of bed & $\kappa_{2}$ & $10^{-6} \mathrm{~m}-\mathrm{s}^{-2}$ \\
\hline Creep activation energy of ice & $E$ & $5^{8.5} \times \mathrm{10}^{3} \mathrm{~J} \mathrm{~mol}^{-1}\left(14 \mathrm{kcal} \mathrm{mol}^{-1}\right)$ \\
\hline Pressure melting coefficient & $c_{0}$ & 0.00 deg $\mathrm{bar}^{-1}$ \\
\hline \multicolumn{3}{|l|}{ Finite difference variables } \\
\hline Longitudinal spatial increment & $\Delta x$ & $200 \mathrm{~m}$ \\
\hline Bed-normal spatial increment & $\Delta y$ & $5 \mathrm{~m}$ \\
\hline Time increment & & \\
\hline During surge phase & $\Delta t_{\mathrm{s}}$ & $0.1 \mathrm{a}$ \\
\hline During quiescent phase & $\Delta t_{\mathrm{Q}}$ & $0.5 \mathrm{a}$ \\
\hline Spatial grid size & & $20 \mathrm{~m} \times 30 \mathrm{~m}$ \\
\hline
\end{tabular}


and the snout velocity $U_{0}$ remain the same for each cycle but the glacier profile and temperature field evolve until, after 25 or more complete cycles, they become perfectly cyclic. At this point the pre-surge and post-surge states can be examined free from any influence of the initial conditions.

\section{Discussion of two-dimensional modelling results}

Table III summarizes the inputs to our two-dimensional model. There is no information concerning the periodicity of surging for the Trapridge Glacier but the most recent surge was around 1940 so if it surges periodically our assumed 37 year cycle is a lower limit. A rather high geothermal flux is required to bring a substantial fraction of the bed to the melting
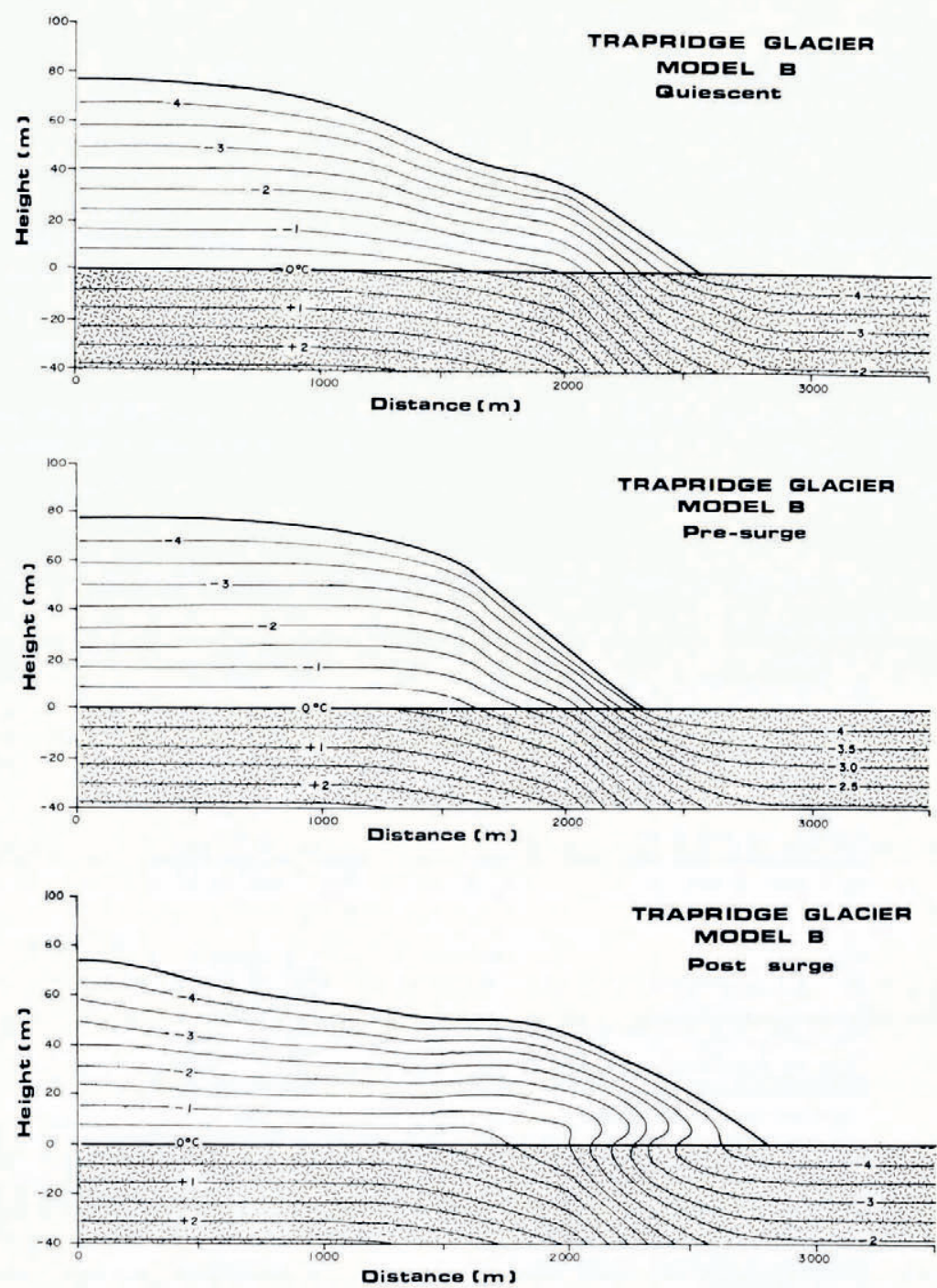

(c)

Fig. 6. Evolution of temperature field for a two-dimensional model of Trapridge Glacier (Model B). Note that the relative amounts of temperate and cold bed change throughout the surge cycle and that immediately following a surge isotherms near the snout are overturned. 
point. No geothermal data are available to support this assumption but it does seem reasonable in view of the Tertiary vulcanism in the region.

Figure 6 shows the glacier surface profile and temperature field at three stages of the surge cycle. In the upper region of the active zone the $0^{\circ} \mathrm{C}$ isotherm follows the bed, but near the snout the proximity of cold surface ice forces it below the bed so that a "cold ring" regime is established. At the onset of a surge the warm basal ice zone is relatively large but after a surge, advection causes it to shrink.

One of the most interesting features in Figure 6 is the overturning of isotherms near the snout at the end of a surge advance (Fig. 6c). The temperature-depth profile in such a region would have a pronounced kink in it; similar features have actually been observed in the Trapridge and Steele Glaciers (Jarvis and Clarke, I975; Clarke and Jarvis, I976). This overturning is a simple consequence of the fact that deep ice temperature near the snout is colder than that of ice farther up-glacier so that a surge displaces warm ice over a cold bed. An unwelcome consequence of the overturned isotherms is that the longitudinal heat conduction term $\partial^{2} T / \partial x^{2}$ in Equation (2) is not negligible so that Equation (10) may not be a satisfactory approximation in the snout region. Averaged over the entire surge cycle, however, the approximation remains acceptable and it is doubtful whether the slight error in computations immediately following a surge greatly changes the temperature distribution near the snout.

Close inspection of Figure $6 \mathrm{c}$ reveals that a thick layer of temperate basal ice did not form as a consequence of the surge. Evidently conduction losses due to advection more than compensated for the heat generated by internal friction during the surge. This is in keeping with Robin's original concept of thermal instability (Robin, I955) but not with his later ideas (Robin, I969). As the bed-normal space increment $y$ was taken as $5 \mathrm{~m}$ a thin temperate layer could pass undetected, but it is very unlikely this was the case.

To this point we have avoided the question of what might cause cyclic surges in a glacier similar to our Model B. It is interesting to compare the relative amounts of temperate and cold basal ice before and after a surge. Shortly after the completion of a surge the temperate zone recedes from the snout region leaving an extended tongue frozen to the bed (Fig. 6a). As the quiescent phase progresses, compressive flow increases the zone of melting at the expense of the frozen zone and ablation of the snout further diminishes the frozen zone (Fig. $6 \mathrm{~b})$. If this were allowed to continue indefinitely almost the entire bed would become temperate. Clearly the situation is unstable and at some point the glacier must begin to advance by sliding (Fig. 6c). At the end of a surge the temperate zone again shrinks and the cycle is completed.

\section{Concluding REMARKs}

We now re-examine the characteristics of surging glaciers in the light of our computational experiments. The calculations of Model A demonstrate that thermal processes can account for the well-defined cycle of advance and quiescence typical of surge-type glaciers as well as the velocity change at the surge onset. It cannot explain the high surge velocities without the assistance of some form of sliding instability and the probable existence of temperate surgetype glaciers remains unexplained.

One of the most attractive features of the thermal control hypothesis is that it offers a simple explanation of the non-random geographical distribution of surge-type glaciers. For the basal temperature to be close to the melting point it is necessary that

$$
\frac{T_{\mathrm{s}}}{\Gamma} \approx-\frac{G}{K_{2}}
$$


where $G$ is the geothermal flux. Thus, according to the thermal control assumption, geothermal flux, ice thickness and surface temperature must be fortuitously related in surge-type glaciers.

This explanation cannot be valid if temperate glaciers surge. Other factors which might control the geographical distribution are geothermal flux, regional variations in bed roughness and permeability, and an accumulation-ablation balance function related to the bed geometry in some special way. Of these, the last seems the most reasonable and is supported by recent computational experiments (Budd and McInnes, I974; Budd, 1975).

If it is conclusively demonstrated that temperate glaciers surge we must accept that thermal instability cannot be the sole explanation of glacier surging. In view of the Robin and Weertman (1973) proposal that dammed basal water flow can lead to enhanced sliding and the onset of a surge, it is interesting to note that water flow at the base of the Rusty and Trapridge is probably thermally dammed. This suggests a possible rapprochement between the thermal instability hypothesis and the Robin-Weertman mechanism: dammed basal water flow may lead to surging and dams may be thermal or mechanical in nature. The radar detection of "lakes" beneath the Antarctic ice sheet (Oswald and Robin, 1973) suggests that attempts to sense water-collection zones at the bases of surge-type glaciers could prove rewarding.

Even if no glaciers surge by thermal instability it is clear from our two-dimensional model calculations that thermal processes must have a major influence on the timing of surges in a large number of cold glaciers and ice sheets.

\section{AcKNowledgements}

This work was financed by grants from Environment Canada, the University of British Columbia Committee on Arctic and Alpine Research, and the National Research Council of Canada. I thank J. W. Hoffmann, G. T. Jarvis, and R. H. Goodman for helpful discussion.

\section{REFERENCES}

Bauer, A. 1955. Contribution à la connaissance du Vatnajökull, Islande: première partie. Zökull, Ár 5, p. I 1-22. Bindschadler, R., and others. Unpublished. Variegated Glacier studies-1973, by R. Bindschadler, W. [D.] Harrison and C. [F.] Raymond. [Manuscript, 1973.]

Budd, W. F. I 969 . The dynamics of ice masses. ANARE Scientific Reports, Ser. A(IV). Glaciology. Publication No. 108.

Budd, W. F. 1975. A first simple model for periodically self-surging glaciers. Fournal of Glaciology, Vol. 14, No. 70, p. $3^{-21}$.

Budd, W. F., and McInnes, B. J. 1974. Modeling periodically surging glaciers. Science, Vol. 186, No. 4167, p. $925^{-27}$.

Carnahan, B., and others. 1969. Applied numerical methods, by B. Carnahan, H. A. Luther and 7. O. Wilkes. New York, John Wiley and Sons, Inc.

Carslaw, H. S., and Jaeger, J. C. 1959. Conduction of heat in solids. Second edition. Oxford, Clarendon Press.

Clarke, G. K. C., and Goodman, R. H. 1975. Radio echo soundings and ice-temperature measurements in a surge-type glacier. Fournal of Glaciology, Vol. 14, No. 70, p. 71-78.

Clarke, G. K. C., and Jarvis, G. T. 1976. Post-surge temperatures in Steele Glacier, Yukon Territory, Canada. Journal of Glaciology, Vol. 16 , No. 74, p. $26 \mathrm{I}-68$.

Classen, D. F., and Clarke, G. K. C. r 971 . Basal hot spot on a surge type glacier. Nature, Vol. 229, No. 5285, p. $48 \mathrm{r}-83$.

Collins, S. G. 1972. Survey of the Rusty Glacier area, Yukon Territory, Canada, 1967-70. Journal of Glaciology, Vol. 1 i, No. 62, p. 235-53.

Davis, J. L., and others. 1973. Radio echo sounding on a valley glacier in East Greenland, by J. L. Davis, J. S. Halliday and K. J. Miller. Journal of Glaciology, Vol. 12, No. 64, p. 87-91.

Evans, S., and Robin, G. de Q. 1966. Glacier depth-sounding from the air. Nature, Vol. 2 10, No. 5039, p. 883-85.

Forsythe, G. E., and Wasow, W. R. ig6o. Finite-difference methods for partial differential equations. New York, John Wiley and Sons, Inc.

Goodman, R. H., and others. 1975. Radio soundings on Trapridge Glacier, Yukon Territory, Canada, by R. H. Goodman, G. K. C. Clarke, G. T. Jarvis, S. G. Collins and R. Metcalfe. Journal of Glaciology, Vol. 14, No. 70, p. $79-84$.

Harrison, W. D. 1972. Reconnaissance of Variegated Glacier: thermal regime and surge behavior. Fournal of Glaciology, Vol. i i, No. 63, p. 455-56. [Letter.] 
Harrison, W. D., and others. 1975. Temperature measurements on Black Rapids Glacier, Alaska, 1973, by W. D. Harrison, L. R. Mayo and D. G. Trabant. (In Weller, G., and Bowling, S. A., ed. Climate of the Arctic. Fairbanks, Geophysical Institute, University of Alaska, p. 350-52.)

Hattersley-Smith, G. 1964. Rapid advance of glacier in northern Ellesmere Island. Nature, Vol. 201, No. 4915, p. 176.

Hattersley-Smith, G. 1969. Recent observations on the surging Otto Glacier, Ellesmere Island. Canadian fournal of Earth Sciences, Vol. 6, No. 4, Pt. 2, p. 883-89.

Hoffmann, J. W., and Clarke, G. K. C. 1973. Periodic temperature instabilities in sub-polar glaciers. (In [International Hydrological Decade.] The role of snow and ice in hydrology. Proceedings of the Banff symposia, September 1972. . . Paris, UNESCO; Geneva, WMO; Budapest, IAHS, Vol, I, p. 445-53.)

Holdsworth, G. 1973 [a]. Barnes Ice Cap and englacial debris in glaciers. fournal of Glaciology, Vol. 12, No. 64, p. $147-48$. [Letter.]

Holdsworth, G. I $973[\mathrm{~b}]$. Evidence of a surge on Barnes Ice Cap, Baffin Island. Canadian Journal of Earth Sciences, Vol. 1o, No. 1o, p. 1565-74.

Jarvis, G. T., and Clarke, G. K. C. 1974. Thermal effects of crevassing on Steele Glacier, Yukon Territory, Canada. Journal of Glaciology, Vol. 13, No. 68, p. 243-54.

Jarvis, G. T., and Clarke, G. K. C. 1975. The thermal regime of Trapridge Glacier and its relevance to glacier surging. Journal of Glaciology, Vol. 14, No. 71, p. 235-50.

Jones, S. J. 1972. Radio depth-sounding on Meighen and Barnes ice caps, Arctic Canada. Ottawa, Environment Canada. Water Resources Branch. Inland Waters Directorate. (Scientific Series, No. 25.)

Joset, A., and Holtzscherer, J.-J. 1954. Expédition franco-islandaise au Vatnajökull, mars-avril i 951 : résultats des sondages séismiques. Fökull, Ár 4, p. I-33.

Lighthill, M. J., and Whitham, G. B. I955. On kinematic waves: I. Flood movement in long rivers. Proceedings of the Royal Society of London, Ser. A, Vol. 229, No. 1 178, p. $281-316$.

Lliboutry, L. A. 1964-65. Traité de glaciologie. Paris, Masson et Cie. 2 vols.

Lliboutry, L. A. 1967. [Reply to] Weertman, J. Sliding of nontemperate glaciers. Fournal of Geophysical Research, Vol. 72, No. 2, p. $5^{2} 5^{-26}$.

Loken, O. H. 1969 . Evidence of surges on the Barnes Ice Cap, Baffin Island. Canadian Journal of Earth Sciences, Vol. 6, No. 4, Pt. 2, p. 899-9or.

Meier, M. F., and Post, A. S. I969. What are glacier surges? Canadian Journal of Earth Sciences, Vol. 6, No. 4, Pt. 2, p. $807-17$.

Miller, K. J. Unpublished. The Cambridge Staunings Expedition 197o. Vol. I. General report and the glaciological projects. [Cambridge, University of Cambridge, Dept. of Engineering, 1972.]

Nye, J. F. 1958. A theory of wave formation in glaciers. Union Géodésique et Géophysique Internationale. Association Internationale d'Hydrologie Scientifique. Symposium de Chamonix, I6-24 sept. 1958, p. 139-54.

Nye, J. F. I 960 . The response of glaciers and ice-sheets to seasonal and climatic changes. Proceedings of the Royal Society of London, Ser. A, Vol. 256, No. 1287, p. 559-84.

Nye, J. F. ${ }_{1963}$. On the theory of the advance and retreat of glaciers. Geophysical Fournal of the Royal Astronomical Society, Vol. 7, No. 4, p. $431-56$.

Nye, J. F. 1971. Causes and mechanics of glacier surges: discussion. Canadian Fournal of Earth Sciences, Vol. 8 , No. 2, p. 306-07.

Oswald, G. K. A., and Robin, G. de Q. 1973. Lakes beneath the Antarctic ice sheet. Nature, Vol. 245, No. 5423, p. $25 \mathrm{I}-54$.

Paterson, W. S. B. 1969 . The physics of glaciers. Oxford, etc., Pergamon Press. (The Commonwealth and International Library. Geophysics Division.)

Post, A. S. 1969. Distribution of surging glaciers in western North America. Journal of Glaciology, Vol. 8, No. 53, p. 229-40.

Ragle, R. H., and others. Unpublished. A pilot study for glacier inventory of Canadian St. Elias Mountains, by R. H. Ragle, S. G. Collins and S. Tolman. [Prepared 1972.]

Rasmussen, L. A., and Campbell, W. J. 1973. Comparison of three contemporary flow laws in a threedimensional, time-dependent glacier model. Fournal of Glaciology, Vol. 1 2, No. 66, p. 361 -73 .

Rist, S. I961. Rannsóknir á Vatnajökli ı66. Hitamælingar, snjómælingar o.fl. Jökull, Ár I I, p. I-I I.

Robin, G. de Q. 1955. Ice movement and temperature distribution in glaciers and ice sheets. Fournal of Glaciology, Vol. 2, No. 18, p. 523-32.

Robin, G. de Q. 1958. Glaciology. III. Seismic shooting and related investigations. Norwegian-British-Swedish Antarctic Expedition, 1949-52. Scientific Results (Oslo, Norsk Polarinstitutt), Vol. 5.

Robin, G. de Q. 1969 . Initiation of glacier surges. Canadian Journal of Earth Sciences, Vol. 6, No. 4, Pt. 2, p. 919 -28.

Robin, G. de Q., and Weertman, J. 1973. Cyclic surging of glaciers. Fournal of Glaciology, Vol. 12, No. 64, p. $3-18$.

Schytt, V. I969. Some comments on glacier surges in eastern Svalbard. Canadian Journal of Earth Sciences, Vol. 6 , No. 4 , Pt. 2, p. $867-73$.

Sharp, R. P. 1947. The Wolf Creek glaciers, St. Elias Range, Yukon Territory. Geographical Review, Vol. 37, No. I, p. $26-52$.

Sharp, R. P. I95I. The glacial history of Wolf Creek, St. Elias Range, Canada. Journal of Geology, Vol. 59, No. 2, p. $97^{-1} 17$.

Thompson, H. R. 1953. Oxford expeditions to Nordaustlandet (North East Land), Spitsbergen. Arctic, Vol. 6, No. 3 , p. $213^{-22}$.

Thorarinsson, S. 1964. Sudden advance of the Vatnajökull outlet glaciers 1930-1964. Jökull, Ár 14, p. 76-89.

Thorarinsson, S. I 969 . Glacier surges in Iceland, with special reference to the surges of Brúarjökull. Canadian Journal of Earth Sciences, Vol. 6, No. 4, Pt. 2, p. 875-82. 
Ward, W. H. 1952. The glaciological studies of the Baffin Island Expedition, 1950. Part II: the physics of deglaciation in central Baffin Island. Journal of Glaciology, Vol. 2, No. I 1, p. 9-1 7, 19-23.

Ward, W. H., and Orvig, S. 1953. The glaciological studies of the Baffin Island Expedition, 1950. Part IV: the heat exchange at the surface of the Barnes Ice Cap during the ablation period. Journal of Glaciology, Vol. 2, No. 13, p. $158-68$.

Weertman, J. 1958. Traveling waves on glaciers. Union Géodésique et Géophysique Internationale. Association Internationale d'Hydrologie Scientifique. Symposium de Chamonix, 16-24 sept. 1958, p. 162-68.

Weertman, J. 1962. Catastrophic glacier advances. Union Géodésique et Géophysique Internationale. Association Internationale d'Hydrologie Scientifique. Commission des Neiges et des Glaces. Colloque d'Obergurgl, $10-9-18-9{ }^{1962}$, p. $3 \mathrm{I}-39$.

Weertman, J. 1967. Sliding of nontemperate glaciers. Journal of Geophysical Research, Vol. 72, No. 2, p. $521-23$.

Weertman, J. 1969. Water lubrication mechanism of glacier surges. Canadian Journal of Earth Sciences, Vol. 6, No. 4 , Pt. 2, p. $929-42$.

Weertman, J. 1972. General theory of water flow at the base of a glacier or ice sheet. Reviews of Geophysics and Space Physics, Vol. 10, No. 1, p. 287-333.

Whitham, G. B. 1974. Linear and nonlinear waves. New York, John Wiley and Sons, Inc.

\section{DISCUSSION}

A. E. BECK: Since I am not a glaciologist I may be missing something, but don't you think it is rather dangerous to propose a thermally based mechanism for surges which considers many things, including the thermal properties of ice, but is not too specific about the thermal properties of the basement material? To clarify my question, let me elaborate a little.

If the basement material and the ice have the same thermal diffusivity; i.e. $K_{\mathrm{b}} / K_{\mathrm{i}}=\mathrm{I}$, then the temperature gradient across the boundary is constant and any heat arriving at the base of the glacier is conducted away. Similarly if $K_{\mathrm{b}} / K_{\mathrm{i}}<\mathrm{I}$. However, if $K_{\mathrm{b}} / K_{\mathrm{i}}>\mathrm{I}$, then some heat will accumulate at the base and possibly lead to melting and a consequent surge. In other words $K_{\mathrm{b}} / K_{\mathrm{i}}$ may be a very important factor in any surge theory, but you assumed it to be always $\mathrm{I}$.

Has anyone measured the thermal properties of basement material beneath a glacier along a surge valley?

G. K. C. Clarke: The thermal properties of the basement are allowed to differ from those of ice in my models. While I agree with you that the ice-rock interface is thermally transparent if the thermal conductivities of ice and rock are taken to be equal, this is only true if the interface temperature is below the pressure melting point. When the ice-rock interface reaches the melting point, basal melting occurs and the boundary condition switches from continuity of flux to an isothermal condition. I think this corresponds to the difference in thermal properties which you seek.

I agree with you that the thermal properties of ice do, in fact, vary rapidly near the melting point but don't think this is a necessary feature of a thermal surge model.

In answer to your final question, the thermal properties of the bed beneath a surging glacier have not been measured and the thermal properties of glacier ice are not that well determined. On several occasions we have tried to make in situ ice conductivity measurements using the "hot-wire" method; we did this by applying power to our thermal probes after the bore hole had completely frozen and measuring the line-heating with our thermistors. The experiments were unsuccessful because the resistance of the wire varied with temperature in an unknown way.

L. Lliboutry: Two conditions are needed to start a surge: (I) the ice-bedrock interface must reach melting point, and (2) the regime must swing from the one with no cavitation, low sliding velocities, high friction, to the one with cavitation, high sliding, low friction. Your model does not consider the intermediate situation: you swing directly from the cold interface to the high-sliding, low-friction situation.

Clarke: I agree that the use of a more detailed sliding theory would improve Model A but have so far found this approach to create more difficulties than it solves. 